Article

\title{
Seasonal Salinization Decreases Spatial Heterogeneity of Sulfate Reducing Activity
}

\author{
Valerie A. Schoepfer ${ }^{1, *,+}{ }^{-}$, Amy J. Burgin ${ }^{1, \ddagger}$, Terry D. Loecke ${ }^{1, \ddagger}$ and Ashley M. Helton ${ }^{2}$ \\ 1 School of Natural Resources, University of Nebraska-Lincoln, Lincoln, NE 68588, USA; \\ burginam@ku.edu (A.J.B.); loecke.terry@ku.edu (T.D.L.) \\ 2 Department of Natural Resources and the Environment, and the Center for Environmental Sciences and \\ Engineering, University of Connecticut, Storrs, CT 06269, USA; Ashley.Helton@uconn.edu \\ * Correspondence: vaschoepfer@gmail.com \\ + Current address: Southern Cross GeoScience, Southern Cross University, P.O. Box 157, Lismore, \\ NSW 2480, Australia. \\ $\ddagger$ Current address: University of Kansas and Kansas Biological Survey, Lawrence, KS 66047, USA.
}

Received: 21 February 2019; Accepted: 28 March 2019; Published: 2 April 2019

\begin{abstract}
Evidence of sulfate input and reduction in coastal freshwater wetlands is often visible in the black iron monosulfide (FeS) complexes that form in iron rich reducing sediments. Using a modified Indicator of Reduction in Soils (IRIS) method, digital imaging, and geostatistics, we examine controls on the spatial properties of FeS in a coastal wetland fresh-to-brackish transition zone over a multi-month, drought-induced saltwater incursion event. PVC sheets $(10 \times 15 \mathrm{~cm})$ were painted with an iron oxide paint and incubated vertically belowground and flush with the surface for $24 \mathrm{~h}$ along a salt-influenced to freshwater wetland transect in coastal North Carolina, USA. Along with collection of complementary water and soil chemistry data, the size and location of the FeS compounds on the plate were photographed and geostatistical techniques were employed to characterize FeS formation on the square $\mathrm{cm}$ scale. Herein, we describe how the saltwater incursion front is associated with increased sulfate loading and decreased aqueous Fe(II) content. This accompanies an increased number of individual FeS complexes that were more uniformly distributed as reflected in a lower Magnitude of Spatial Heterogeneity at all sites except furthest downstream. Future work should focus on streamlining the plate analysis procedure as well as developing a more robust statistical based approach to determine sulfide concentration.
\end{abstract}

Keywords: sulfate reduction; geostatistics; homogeneity; soil moisture; concentration; indicator of reduction in soils; salinization; incursion; saltwater; iron monosulfide

\section{Introduction}

Sulfate $\left(\mathrm{SO}_{4}{ }^{2-}\right)$ reducing activity is a key metabolic process in wetland sediments, especially in those sediments exposed to elevated sea salts and the associated higher concentrations of $\mathrm{SO}_{4}{ }^{2-}[1,2]$. In iron (Fe) rich sediments, common along the United States eastern seacoast, $\mathrm{SO}_{4}{ }^{2-}$ reduction often results in the precipitation of Fe(II) monosulfide complexes [1,3,4] (FeS, Supplemental Information Figure SI1). Current climate change scenarios predict rising ocean levels, bringing with this salt water the potential for new FeS compounds to form further inland [4,5]. These FeS compounds at the fresh- and saltwater interface may play a large role in determining $\mathrm{pH}$ [6], as well as toxic and trace element mobility and nutrient sequestration [7,8]. Salinizing wetlands likely undergo dynamic redox behaviour through their episodic flooding and draining cycles [5,9]. Oscillating redox conditions will periodically oxidize FeS compounds, lowering the $\mathrm{pH}$ and mobilizing trace metals $[9,10]$. Therefore, the quantification of FeS patterns may be useful while developing mitigation 
plans for preventative actions against increased sulfidization, metal mobility, and wetland degradation in these transitioning wetlands.

Common $\mathrm{FeS}_{\mathrm{x}}$ quantification tools such as acid volatile sulfide (AVS) or chromium reducible sulfur (CRS) rely on sediment homogeneity for upscaling. In acidic and historically $\mathrm{SO}_{4}{ }^{2-}$ rich sediments [11], these techniques are appropriate. In soils and sediments that experience variable inundation or salinization, homogenizing samples at the cubic centimetre scale may mask important spatial complexity. For example, soils in the fresh- and saltwater boundary zone, as well as those newly inundated sediments will often show fine scale heterogeneity in chemical parameters, including $\mathrm{FeS}_{\mathrm{x}}$, as demonstrated by large errors between replicate samples from the same square-meter location $[3,12,13]$. Furthermore, there could also be a much more inherent error, where FeS can be a very small fraction of the total bulk sediment $[3,14]$. Consequently, fine scale heterogeneity is not often easy to measure, especially at the microbial scale on which $\mathrm{SO}_{4}{ }^{2-}$ reduction occurs [15-18]. As such, both Viollier et al. [19] and Stockdale et al. [17] state the ongoing need for measurements of microbial reduction at a fine scale and in heterogeneous landscapes over time.

To overcome fine scale heterogeneity, recent methods for chemical characterization rely on solute equilibration in a diffusive gel (DGT), diffusive equilibrium in thin films (DET), or planar optodes [13, $16-18,20,21]$. These methods involve reactions and processes that mimic belowground photography and are typically used in a 1-D, vertical fashion, although 2-D studies are becoming more common as research dictates the need for more spatial resolution and also the lack of replicability in 1-D, vertical profile studies [13]. These methods are useful, and provide detailed information on the spatial heterogeneity of aqueous components in sediments and porewaters [13]. DET and DGT have numerous practical drawbacks, however [13], including extensive setup, careful handling through the gel making process, and chemical characterization in the lab [7,22], or in the case of optodes, specialized lab aquaria/microcosms [13]. These requirements make it often impractical to use in remote field locations. In addition, analysis typically has been limited to concentration gradients presented in photo format [12]. This leads to a lack of quantitative information about a key metabolic pathway in the most important and dynamic time of the year [3,23].

Here, we attempt to overcome these challenges by employing a modified FeS quantification method that uses the Indicator of Reduction in Soils (IRIS) method [24,25], camera/computer imaging, and geostatistical analyses. While the IRIS method has been established in the literature [24], using numerical and geostatistical analysis on IRIS images is novel. IRIS is commonly a visual and qualitative method [24,26,27]. Previously, this method has been used to document the presence or absence of reducing conditions or broadly characterize $\mathrm{SO}_{4}{ }^{2-}$ reduction $[24,26]$, but has not yet been used to identify individual complex size or area, or quantify the spatial patterns within these complexes. Spatial patterns, however, have previously been documented in regards to soil nitrogen presence as well as denitrification activity [28,29], plant root presence [30], soil carbon [31], and soil fertility [30].

Our modification of the IRIS technique results in a high-resolution image of in situ FeS precipitation dynamics in a sediment and some new metrics associated with FeS quantification by capturing a view of the microbial and mineralogical activity of a sediment at the scale at which it occurs. This modified method is practical in remote field situations where flatbed scanners, typical of DGT and DET measurements, are not available or feasible. The IRIS method is inexpensive, and the physical setup is more robust for field locations. In addition to qualitative and visual data [24], geostatistics is used here to numerically quantify the spatial heterogeneity of the FeS complexes. The modified method presented herein provides previously unreported measures of FeS complex formation that yield valuable information on trends within a changing landscape.

The objective of this study is to 1) create a more numerically robust characterization of the IRIS technique and 2) apply and test whether this numerical characterization can reflect changes in porewater chemistry as a result of overland salt water incursion. A naturally occurring saltwater reaction front as a result of saltwater incursion in coastal North Carolina provides a unique natural experiment to examine the usefulness of the modified IRIS method in capturing belowground microbial 
activity and how it may change with respect to time and/or distance along the wetland. Trends within these numerical analyses can be compared across time and location, which is not currently possible with the visual and qualitative measurements typically employed with the IRIS method [26,27].

As such, elevated sea salts are suspected to be a major driving force in the heterogeneity of $\mathrm{SO}_{4}{ }^{2-}$ reducing activity in the wetland. Specifically, we hypothesize that the Magnitude of Spatial Heterogeneity will decrease at the peak of incursion (when sea salt concentrations are most elevated) and indicate a more homogenous sediment. To test this hypothesis, we used the modified IRIS method [27] to quantify changes in $\mathrm{SO}_{4}{ }^{2-}$ reducing heterogeneity during a 2012 saltwater incursion event, described in detail by Schoepfer et al. [3]. Briefly, we sampled four sites along a salinity transect in June at the beginning of the event, in July and August as the event intensified and peaked, and in October as salinity decreased at the end of the incursion event.

\section{Materials and Methods}

\subsection{Site Description}

The Timberlake compensatory mitigation wetland in Tyrell county, North Carolina is a 440 ha former agricultural field that was restored to a freshwater pocosin (evergreen shrub-scrub) wetland and is seasonally influenced by overland saltwater incursion [3,32-35]. It is located within the humid sub-tropical Albermarle Peninsula, and the majority of the land area is under $2 \mathrm{~m}$ elevation $[29,30,32,33]$. The upstream portion of the channel (distance $>1 \mathrm{~km}$, Figure 1) remains largely fresh due to active pumping to allow for agriculture, while downstream areas closer to the salt source (distance $<0.5 \mathrm{~km}$ ) fluctuate in specific conductivity (Figure 1, insert) due to seasonal, drought-induced saltwater incursion $[3,29,32,33]$. Water flow from the site moves bi-directionally as a result of groundwater, rainfall runoff and wind-driven tides [33-37].
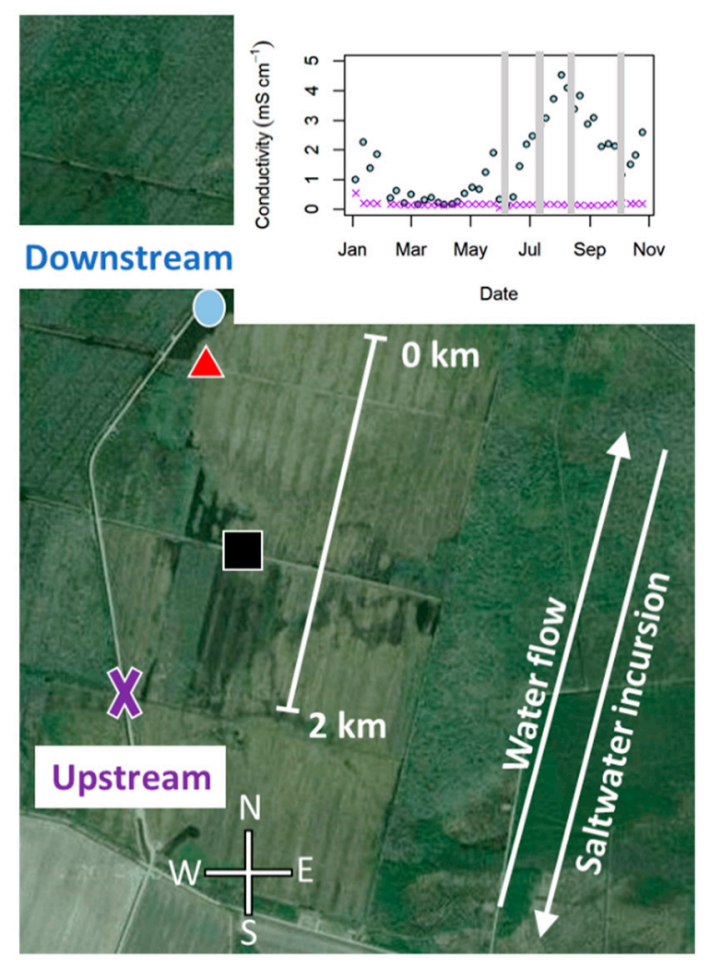

Figure 1. Map of sampling locations (colored shapes) along the salt-influenced downstream (northern end) to largely freshwater upstream (southern end) two kilometer transect. Freshwater flows south to north, while saltwater incursion pushes inland north to south. Insert depicts the specific conductivity of surface water (light blue circles = downstream site, purple crosses = upstream site) over the year [3]. The sampling dates are indicated by grey vertical lines. 


\subsection{Traditional Soil and Porewater Chemistry}

Supporting chemical data were gathered alongside the IRIS data to characterize the wetland using traditional methods. Triplicate $5 \mathrm{~cm}$ diameter soil cores to a depth of $15 \mathrm{~cm}$ were taken using a slide hammer attachment at each sampling location (Figure 1) at four times throughout the saltwater incursion event (early June, July, August, and October). Care was taken to preserve the anoxic characteristics of each core by capping them underwater. Soil cores were stored on ice and transported to the laboratory within $24 \mathrm{~h}$ and refrigerated until analysis.

Each soil core was extruded to a depth of $5 \mathrm{~cm}$, sieved $(2 \mathrm{~mm})$, and homogenized within $72 \mathrm{~h}$. Duplicate soil cores were combined to provide sufficient sediment for analysis. Water extractable chloride $\left(\mathrm{Cl}^{-}\right)$and sulfate $\left(\mathrm{SO}_{4}{ }^{2-}\right)$ content in each soil sample were determined by adding $2.5 \mathrm{~g}$ field wet soil to $25 \mathrm{~mL}$ deionized water. Samples were placed on a rotary shaker table for four hours at $150 \mathrm{rpm}$, followed by centrifugation at $3400 \mathrm{rpm}$ for $15 \mathrm{~min}$. The supernatant was filtered through a $0.7 \mu \mathrm{m}$ GF/F Whatman filter. Concentrations of $\mathrm{Cl}^{-}$and $\mathrm{SO}_{4}{ }^{2-}$ were measured using a Dionex ICS-2000 ion chromatograph (Dionex Corporation, Sunnyvale, CA, USA) with a detection limit of $0.03 \mathrm{mg} \mathrm{L}^{-1}$ for $\mathrm{Cl}^{-}$and $0.01 \mathrm{mg} \mathrm{L}^{-1}$ for $\mathrm{SO}_{4}{ }^{2-}$. Soil moisture was calculated through oven drying a 5-10 g soil sample at $60^{\circ} \mathrm{C}$. The soils were then reweighed to determine soil water content ( $\mathrm{g}$ water $\mathrm{g}$ dry soil ${ }^{-1}$ ). Porewater $\mathrm{Fe}(\mathrm{II})$ was taken from the initial porewater values in the $\mathrm{Fe}(\mathrm{III})$ reduction rate assays of Schoepfer et al. [3]. Fe(II) was determined using the ferrozine colorimetric method [38].

Acid volatile sulfide (AVS) and chromium reducible sulfur (CRS) were characterized as in Schoepfer et al. [3]. Briefly, within a Coy anaerobic chamber, $0.5 \mathrm{~g}$ homogenized sediment from the surface $3 \mathrm{~cm}$ was assessed for both AVS and CRS using a modified purge and trap procedure [39,40]. Modifications enabled five samples to be assessed at once using a manifold system and did not change any chemical ratios in the purge/trap procedure.

\subsection{Indicator of Reduction in Soils}

We assessed soil chemical heterogeneity, namely $\mathrm{SO}_{4}{ }^{2-}$ reduction heterogeneity, by employing a modified Indicator of Reduction in Soils (IRIS) technique [24,41]. IRIS is an in situ visual method developed to quantify the formation, concentration, size and distribution of FeS complexes in wetland sediments [24]. We modified the method by painting sanded PVC sheets with an Fe(III) oxide paint $(10 \times 15 \mathrm{~cm}$, Figure 2a) instead of employing the recommended round PVC pipes. The paint is made by precipitating $\mathrm{FeOOH}$ (uncharacterized ferrihydrite) from a solution of $\mathrm{FeCl}_{3}$ and $\mathrm{NaOH}$ [24].

Five IRIS plates were deployed vertically in the wetland within a square meter at each of four sites throughout the wetland (Figure 1). A mallet was used when necessary to assist in the insertion of each plate, however sites were largely underwater and the formerly dense agricultural soil was loosened through constant waterlogging, decomposition, and soil-floc formation. The top edge of each plate was inserted flush with the ground surface. The plates incubated belowground for $24 \mathrm{~h}$, four times during the incursion event (June, July, August, October), within one to two days of soil core collection. Black FeS complexes precipitate on the sheets when aqueous sulfide is present in the pore water [24] (Figure 2a). After incubation, the plates are removed from the sediment, gently washed to remove debris, patted dry, and photographed immediately ( $<1 \mathrm{~min})$ as the black FeS complexes fade within minutes to hours as they oxidize [24].

Digital photographic data was later analyzed to quantify metrics related to heterogeneity in $\mathrm{SO}_{4}{ }^{2-}$ reducing activity (Figure 2b, Supplemental Information Figure SI2). Digital images, cropped and set to $140 \%$ red saturation in Photoshop [24] (alternatively, other free image manipulation software), eliminated variation due to differences in orange $\mathrm{FeOOH}$ paint thicknesses across the plate. Images were then processed according to two methods: (1) greyscale, for concentration analysis (Figure 2c), and (2) black and white, for all other analyses (Figure 2d). For greyscale concentration analysis, sodium sulfide standard solutions were prepared at concentrations of approximately $0,0.5,8.5,32.5$, and $165.6 \mathrm{mM}$ sulfide (Supplemental Information Figure SI1). Plates were soaked in each anoxic standard solution for $24 \mathrm{~h}$, removed, patted dried, and photographed. Using a histogram function 
in ImageJ [42], average greyscale color intensity (0-255) was determined for each standard plate. This number was inverted so a value of zero was representative of a white pixel and 255 represented black. The log standard concentration was plotted against the log average standard plate intensity ( 0 through 255) with an $r^{2}$ value of 0.987 . Plates deployed in the wetland were then assigned an average color intensity value with ImageJ, which was used to calculate concentration. However, this is an average value calculated over the whole plate, where few dark complexes may register a similar average value to one large light complex. For the second method of black and white analysis, images were converted to black and white using the threshold tool in Image (Figure 2d). We used ImageJ [42] to extract numerical parameters such as the average complex size (in pixels), complex location ( $\mathrm{x}-\mathrm{y}$ coordinate system), and the number of individual complexes.

a.

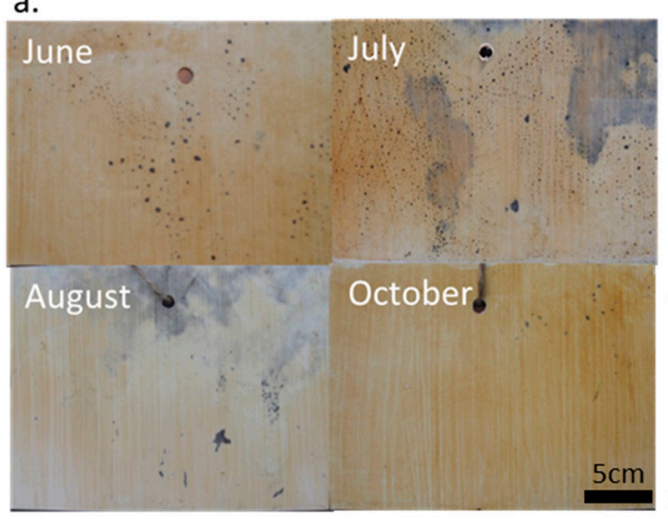

b.

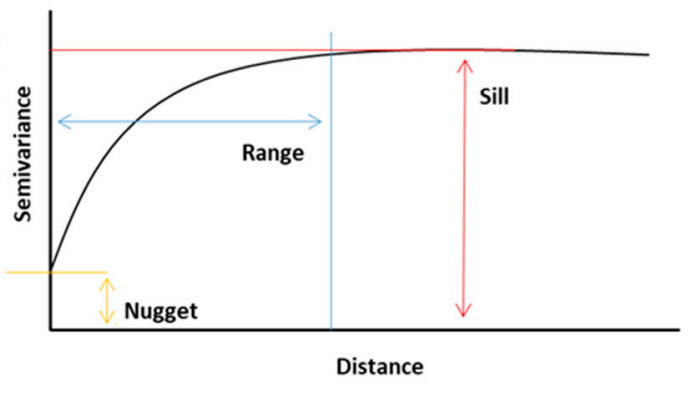

Nugget: Inherent variability at units too small for plates to measure Range: Grain size where autocorrelation is zero

Sill: Variance in the sample, or the maximum observed variability

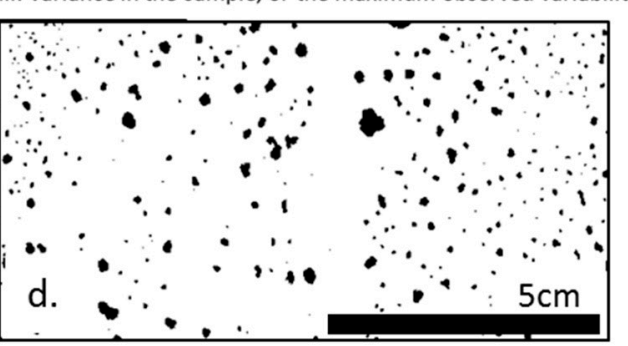

Figure 2. (a) Representative IRIS plates at each sampling date. FeS appears as black complexes, either discretely or as aggregated units. (b) A model semivariogram and the variables extracted. And, a raw plate showing FeS complexes transformed to (c) greyscale and (d) black and white.

\subsection{Geostatistical Analysis}

Following numerical analysis, semivariograms of the locations of the black pixels against the white background were constructed in R, using the packages "gstat,"[43] "sp,"[44,45] "plyr,"[46] "dostats,"[47] and "SiZer"[48] (Supporting information R code S1). Using a subset of 5000 random pixels on each plate, five replicate semivariograms were constructed. Five replicate plates were analyzed, for a total of 25 semivariograms per site. From each semivariogram, parameters such as the range, nugget and sill (Figure $2 b$ ) were extracted through a looping process in $R$ and the 25 values were averaged into one value for plotting. The top three $\mathrm{cm}$ of each plate are described using this method, as additional variation in all parameters was apparent with depth and confounded results.

This process was conducted at four timepoints across the incursion event to effectively create a 4-D map of the belowground FeS characteristics of the wetland $(15 \mathrm{~cm}$ width and $3 \mathrm{~cm}$ depth of the plate in the sediment over a two kilometer transect over time). Of the geostatistical parameters, the nugget (Figure 2b) measures the inherent variability on each plate at short distances [31]. A larger nugget, therefore, indicates more stark differences in color between one spot and another (i.e., the difference between the background white and a distinct black complex as compared to a lower nugget, homogenous plate, either with many complexes or few complexes). The nugget, however, 
does not indicate the presence or absence of complexes or the number of complexes, rather the change between complex locations at the plate level (Supplemental Information Figure S5).

The range, or grain size, is the lag value at which autocorrelation is zero (Figure $2 b$ ). Beyond this distance, there is little to no autocorrelation and values are independent. The sill is the variance in the sample, or the maximum observed variability (Figure $2 b$ ). From these, the magnitude of spatial heterogeneity (MSH) can be calculated as the inverse of the relative nugget effect (sill/[sill+nugget]) [49]. This value is zero when there is no spatial heterogeneity (complete homogeneity) and one when the sample is completely heterogeneous [49].

\subsection{Relationships between Tranditional Chemistry and IRIS Analysis}

We expect traditional soil and porewater chemistry to be related to $\mathrm{FeS}$ activity [3]. Iron(II) sulfide precipitation is a function of soil $\mathrm{Fe}(\mathrm{III})$ reduction, saltwater- $\mathrm{SO}_{4}{ }^{2-}$ introduction, microbial $\mathrm{SO}_{4}{ }^{2-}$ reduction, and FeS precipitation. Traditional soil and porewater chemistry quantify both the free and aqueous forms of the compounds as well as the solid and precipitated forms of the species. However, not all compounds under consideration are conservative.

For example, Fe(II) is an integral component of FeS. However our quantification methods measure aqueous $\mathrm{Fe}(\mathrm{II})$ remaining in the soil porewater, not bound to any constituents [3]. Consequently, the measured quantity is a mirror image of what has precipitated, and thus, we expect an increase in aqueous $\mathrm{Fe}(\mathrm{II})$ to be correlated with a decrease in precipitated FeS.

We also predict the $\mathrm{SO}_{4}{ }^{2-}$ concentrations to be time dependent with respect to FeS precipitation; $\mathrm{SO}_{4}{ }^{2-}$ must first reduce to sulfide, then precipitate. Oxidized $\mathrm{SO}_{4}{ }^{2-}$ is predicted to be a mirror image of $\mathrm{FeS}$ precipitation as well, as $\mathrm{SO}_{4}{ }^{2-}$ will decrease with reduction and precipitation. However, this can potentially become more complicated with the anticipated $\mathrm{SO}_{4}{ }^{2-}$ pulse travelling through the wetland with overland saltwater incursion, and the non-conservative nature of $\mathrm{SO}_{4}{ }^{2-}$. This could result in no direct relationship between measured $\mathrm{SO}_{4}{ }^{2-}$ and $\mathrm{FeS}$ quantification.

We also expect the AVS and CRS measures to be directly correlated to the IRIS plate measures. Both quantify the precipitated and solid phase forms of FeS rather than its aqueous formation components. As such, a more direct comparison should be clear between AVS, CRS, and the IRIS method characterization.

\subsection{IRIS Method Advantages and Limitations for Measuring FeS}

The field work associated with the IRIS plate method is minimal. The PVC sheets are robust and a mallet can be used to insert the sheets into dense sediment when necessary, although care must be taken to not scratch the $\mathrm{FeOOH}$ paint in dry sediments. Two trips to the wetland are needed, however, as the plates require a 24-h incubation. High resolution digital photography is sufficient and digital scanners are not required, unlike similar methods. Additionally, there is no hazardous chemical waste, unlike traditional AVS and CRS techniques. Once cut and sanded, the PVC sheets can be repainted with $\mathrm{FeOOH}$ and reused. While there are significant physical advantages to using the modified IRIS method, the greatest advantages are from the new variables that can be assessed. Although a limitation of this method is the lengthy processing time of each photo, pixel and numerical analysis in ImageJ can be streamlined through macros.

Additional considerations during plate photography include consistent lighting which may be difficult depending on cloud cover or flash use. Differences in lighting may incur inaccuracies when determining pixel darkness if the concentration of each FeS compound is being analyzed. One possible solution is photographing against a white background to normalize the white balance of each photograph during the analysis stage. Concentration can be measured on a pixel by pixel basis, as was done here (Supplemental Information Figure S5), however was finally averaged across the entire plate to create one value for reporting in this study. Alternative statistical reporting methods must be employed to represent concentration using the IRIS method. 


\section{Results}

\subsection{Soil and Porewater Chemistry}

Soil moisture was greatest at the most downstream site (distance $=0 \mathrm{~km}$ ) at all sampling timepoints. Gravimetric soil moisture content ranged from approximately $80 \%$ at the downstream site to approximately $40 \%$ at the upstream site, and decreased with distance (Figure 3a).
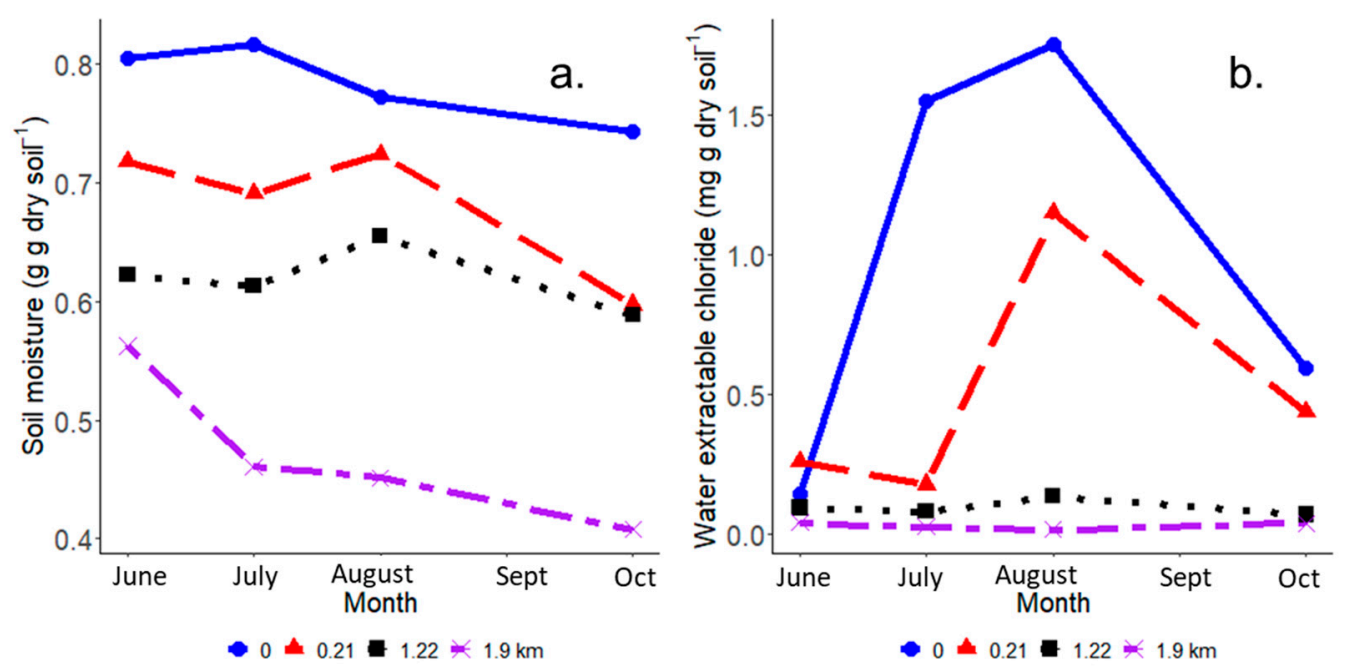

Figure 3. (a) Gravimetric soil moisture ( $\mathrm{g}$ water $\mathrm{g}$ dry soil $\left.{ }^{-1}\right)$ and (b) Water extractable $\mathrm{Cl}^{-}\left(\mathrm{mg} \mathrm{Cl}^{-} \mathrm{g}\right.$ dry soil ${ }^{-1}$ ) with distance from the most downstream site $(\mathrm{km})$ per month (June-October).

Water extractable $\mathrm{Cl}^{-}$was generally greatest at the downstream site (Figure 3b), and also varied with time, peaking in August at $\sim 1.7 \mathrm{mg} \mathrm{g}^{-1}$ dry soil. The $\mathrm{Cl}^{-}$content peaked in August at the second site around $1.2 \mathrm{mg} \mathrm{g}^{-1}$. Water extractable $\mathrm{Cl}^{-}$at upstream sites (distance $>1 \mathrm{~km}$ ) varied little over time, remaining $<0.25 \mathrm{mg} \mathrm{g}^{-1}$ throughout the saltwater incursion event.

Traditional descriptive measures of $\mathrm{FeS}$ activity included water extractable $\mathrm{SO}_{4}{ }^{2-}$, porewater $\mathrm{Fe}(\mathrm{II}), \mathrm{AVS}$, and CRS. Water extractable $\mathrm{SO}_{4}{ }^{2-}$ varied with distance and time (Figure $4 \mathrm{a}$ ). Similar to $\mathrm{Cl}^{-}, \mathrm{SO}_{4}{ }^{2-}$ was highest in the most downstream site and decreased with distance from this downstream site. However, while $\mathrm{Cl}^{-}$peaked in August, $\mathrm{SO}_{4}{ }^{2-}$ peaked earlier in July. Water extractable $\mathrm{SO}_{4}{ }^{2-}$ reached a maximum of approximately $0.2 \mathrm{mg} \mathrm{g}^{-1}$ in July (Figure 4a).

Porewater Fe(II) concentrations did not follow a similar pattern to water extractable $\mathrm{SO}_{4}{ }^{2-}$ or $\mathrm{Cl}^{-}$concentrations. Rather, they were somewhat mirrored with respect to time. Porewater Fe(II) was between 2 and $4 \mu \mathrm{g} \mathrm{Fe}(\mathrm{II}) \mathrm{g}$ dry soil $^{-1}$ in June throughout the site. Concentrations decreased to near the detection limit in July and August, and generally increased to concentrations higher than the pre-incursion levels in October. In October, porewater Fe(II) content was greatest at the two furthest downstream sites with concentrations near $8 \mu \mathrm{g}$ Fe(II) $\mathrm{g}$ dry soil $^{-1}$ and decreased upstream.

Direct measures of $\mathrm{FeS}_{\mathrm{x}}$ formation include AVS and CRS. Measured concentrations of AVS were too low and too variable between replicates and sites to accurately determine patterns amidst large error terms [3]. Chromium reducible sulfur, however, demonstrated clear patterns with distance and time (Figure 4c). By far, the highest CRS values were at the furthest downstream site in August at the peak of the saltwater incursion event, greater than $150 \mu$ moles $g$ dry weight ${ }^{-1}$. Values were near the detection limit at $1.22 \mathrm{~km}$. Chromium reducible sulfur was not measurable at the most upstream site due to low soil moisture and $\mathrm{SO}_{4}{ }^{2-}$ concentrations. 

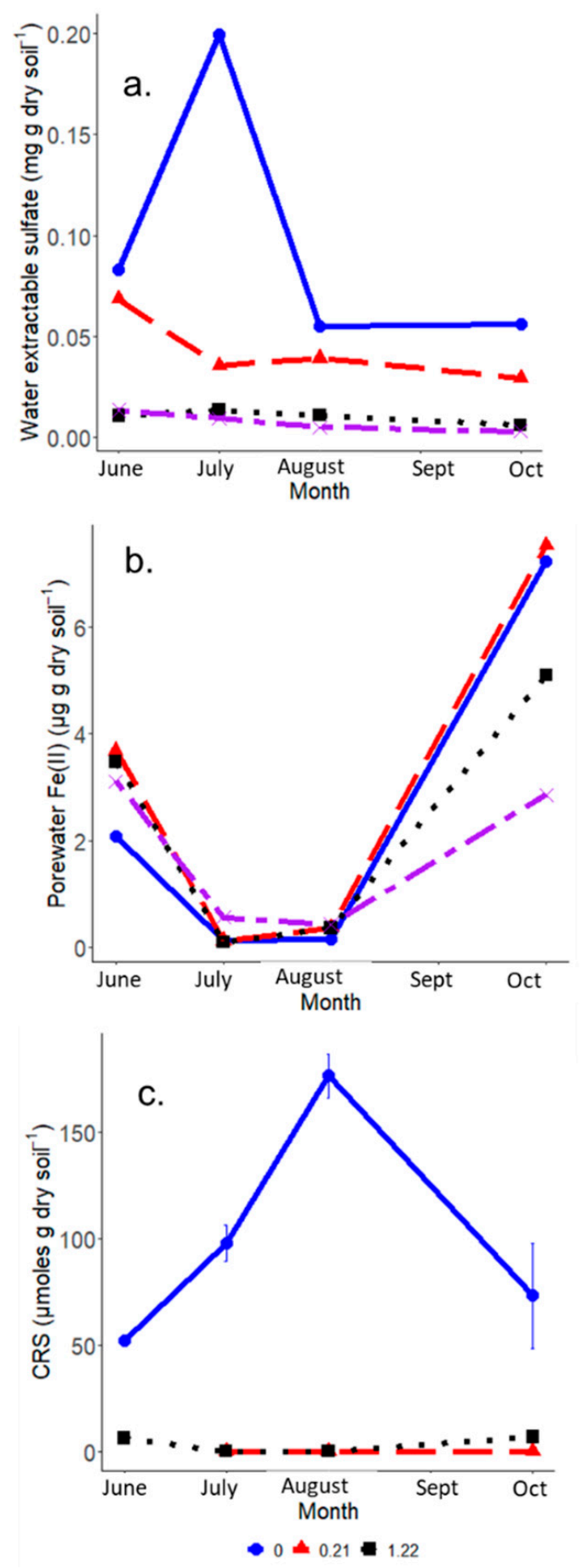

Figure 4. (a) Water extractable $\mathrm{SO}_{4}{ }^{2-}$ (mg g dry soil ${ }^{-1}$ ), (b) $\mathrm{Fe}(\mathrm{II})$ ( $\mu \mathrm{g} \mathrm{Fe}(\mathrm{II}) \mathrm{g} \mathrm{dry} \mathrm{soil}^{-1}$ ), and (c) chromium reducible sulfur (CRS, $\mu$ moles $\mathrm{g}$ dry soil $^{-1}$ ) versus distance from the downstream site $(\mathrm{km})$ and through time (month). Error bars denote standard errors.

\subsection{IRIS Method Indicators of Altered FeS Activity Across the Saltwater Incursion Gradient}

The total number of FeS complexes, derived from IRIS plate quantification, follow a unique pattern in space and time. The greatest number of complexes were not found at the most downstream site, but slightly more inland, at $0.21 \mathrm{~km}$ (Figure 5a). This contrasts with the measured $\mathrm{SO}_{4}{ }^{2-}$ and $\mathrm{Cl}^{-}$concentrations. The number of complexes also were greater mid-incursion (July) and decreased at the height of incursion (August). Specifically, the highest number of FeS complexes occur in July at approximately $0.21 \mathrm{~km}$ from the downstream outlet, with over 2000 individual complexes. 
After August and at the freshwater end, the number of complexes decreases rapidly to $<500$ complexes per $45 \mathrm{~cm}^{2}$. The peak in the number of individual FeS complexes occurs while the incursion event intensifies in July, and decreases in August at the peak of the incursion event when water extracted chloride is highest.
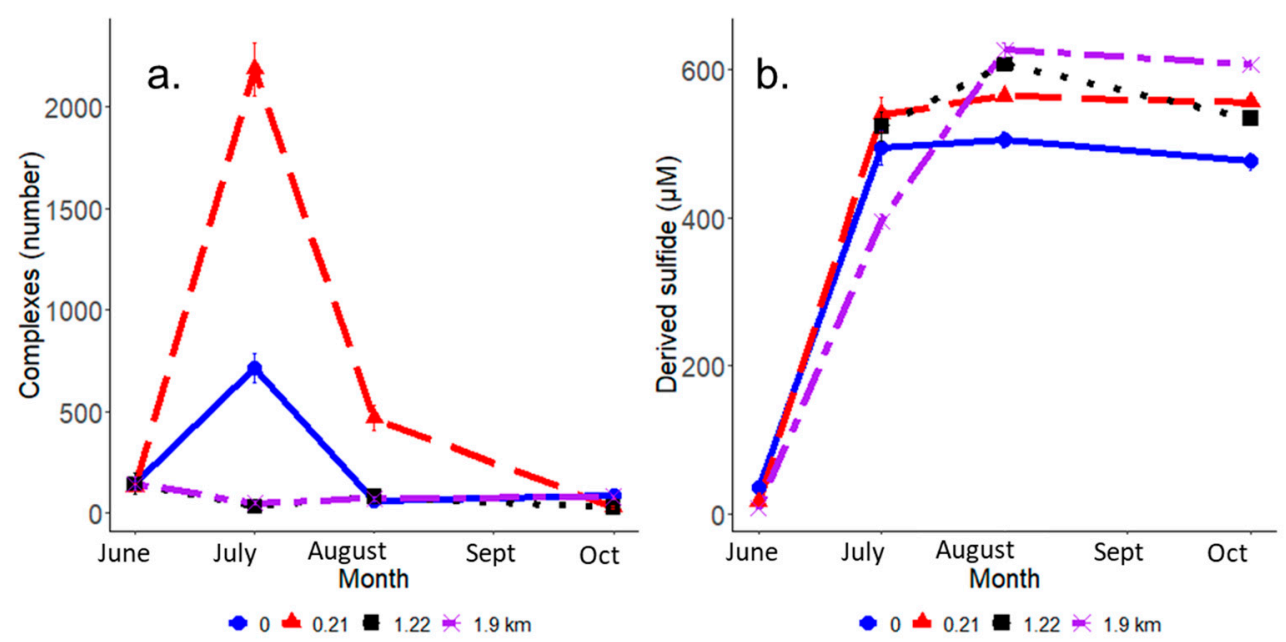

Figure 5. IRIS plate derived patterns in (a) the number of complexes per $45 \mathrm{~cm}^{2}$ and (b) the calculated sulfide concentration ( $\mu \mathrm{M}$ sulfide) averaged across each plate across wetland distance $(\mathrm{km})$ and per month. Values are an average across the total $3 \times 15 \mathrm{~cm}$ plate, averaging all white, grey, and black spaces. Error bars denote standard errors.

The average sulfide concentration (from IRIS-derived FeS complex concentration) of the top three $\mathrm{cm}$ of the plate (Figure $5 \mathrm{~b}$ ) was below the detection limit in June ( $250 \mu \mathrm{M}$ sulfide) at all sites. The sulfide concentrations during the rest of the saltwater incursion event were much higher but similar across the site (approximately 500-600 $\mu \mathrm{M}$ sulfide). Derived sulfide concentrations also increased further upstream. Thus, the IRIS plate derived sulfide concentration patterns did not directly follow the incursion derived soil and porewater chemistry patterns across space and time.

Geostatistical parameters demonstrate distinct zonation by month and distance along the salt-influenced to freshwater gradient. The nugget represents the inherent variability on the site, or the sharp change in complex presence between two sampling points on the same plate (Supplemental Information S3). This was greatest in July at the two most downstream sites ( 180 pixels) and this value decreased rapidly with space and time ( $<50$ pixels), following the saltwater pulse (Figure $6 a)$. The Magnitude of Spatial Heterogeneity (MSH) is a summary statistic based on the inverse nugget effect, or the geostatistical parameters of the sill and nugget [49]. Before the incursion event, the farthest downstream site was most homogenous while the inland sites were more heterogeneous (Figure 6b). This trend flipped in August at the height of incursion, with the inland sites more homogenized than the most downstream site.

A histogram for each month was created to document the frequency of each plate-averaged concentration found throughout the 25 replicate plates (Figure 7a-d). In June, FeS complexes were visible on some plates, but the concentrations found were below detectable limits (Figure 7a). In July, more derived sulfide was present on the plates (Figure $7 \mathrm{~b}$ ) and the overall number of plates with measurable sulfide concentrations rose. There were higher sulfide concentrations in August (Figure 7c) and October (Figure 7d), with August displaying the highest concentrations. 

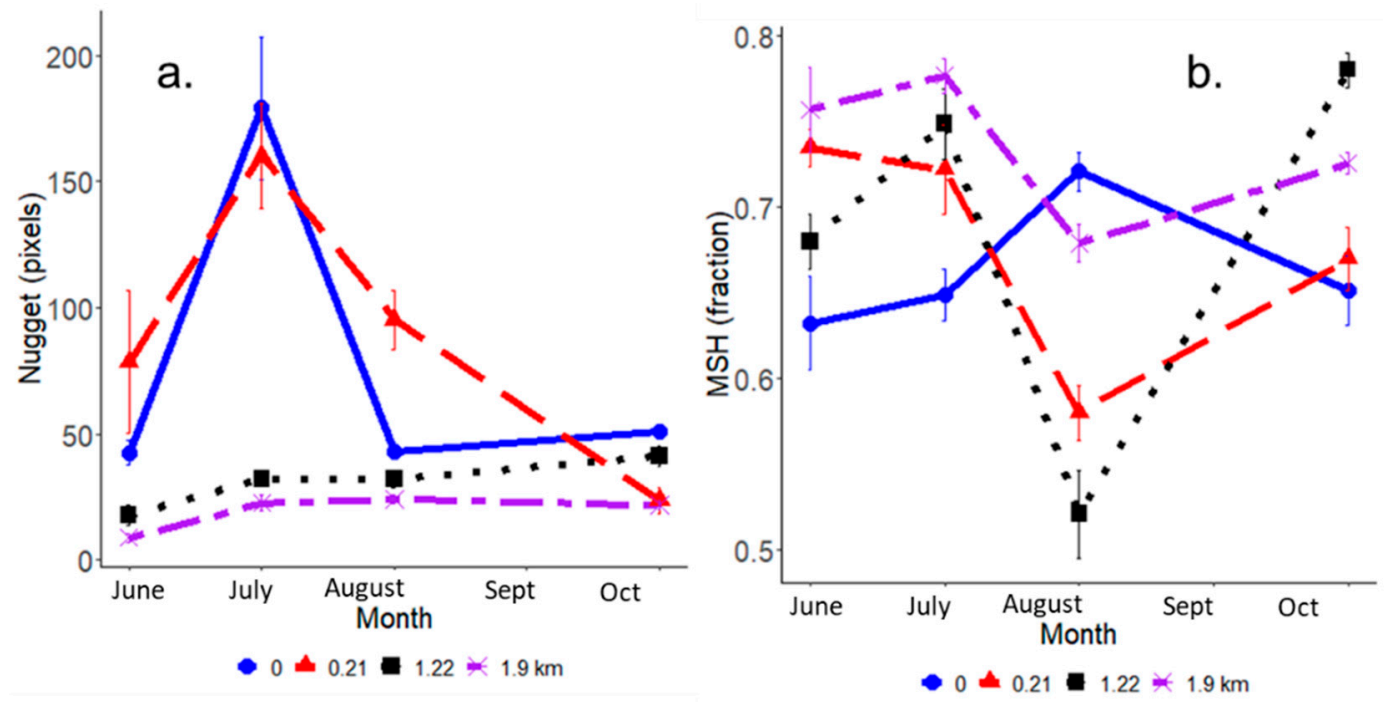

Figure 6. IRIS derived patterns in the (a) nugget (pixels) and in the (b) fractional value of the magnitude of spatial heterogeneity across distance in the wetland $(\mathrm{km})$ and by month. Nugget values are calculated as a mean of 25 replicate semivariograms from each site and depth. The MSH is a summary statistic based off the geostatistical parameters. When the MSH equals 1, the site is completely heterogeneous. Error bars denote standard errors.

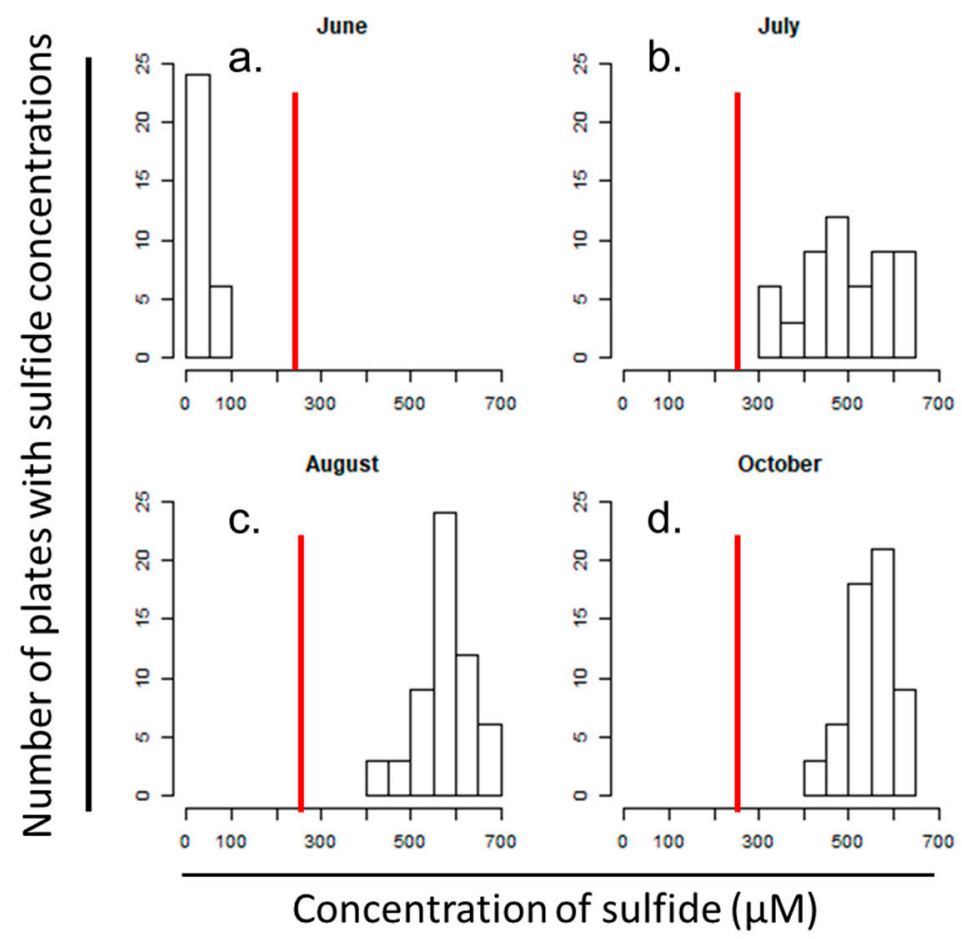

Figure 7. IRIS plate derived sulfide concentrations across site for each month throughout the incursion season. The frequency of each plate-averaged concentration is displayed on the y axis and the average concentration per plate is binned on the $\mathrm{x}$ axis in (a) June, (b) July, (c) August, and (d) October. Red vertical lines denote the detection limit of derived sulfide. Values below this limit indicate that FeS complexes were present, but concentration values are not reliable. Sulfide concentrations represent the average of each white, grey, and black pixel on the plate. 


\section{Discussion}

\subsection{A Saltwater Reaction Front}

A reaction front develops within the Timberlake wetland with the progression of saltwater incursion, resulting in gradients in water chemistry both throughout the incursion season and with distance along the wetland. This front moves inland with time and dissipates at the end of the summer season with the seasonal flushing of saltwater by rainfall. The reaction front can be traced through both $\mathrm{Cl}^{-}$(Figure 3b) and $\mathrm{SO}_{4}{ }^{2-}$ concentrations (Figure $4 \mathrm{a}$ ) in the sediment, which were expected to increase with saltwater incursion [32]. Water extracted $\mathrm{Cl}^{-}$increased in July at the downstream site and remains high through August. At $0.21 \mathrm{~km}$, this pulse is delayed, peaking in August at a lower concentration. Sulfate is typically non-conservative [4] and may be expected to decrease with increased microbial $\mathrm{SO}_{4}{ }^{2-}$ reduction mid-event [3]. Supporting this hypothesis, $\mathrm{SO}_{4}{ }^{2-}$ is highest at the most downstream site in July and decreases drastically in August, at a period of highest $\mathrm{SO}_{4}{ }^{2-}$ reduction rates [3].

The incursion-mediated gradient in $\mathrm{SO}_{4}{ }^{2-}$ concentration is in contrast to the pattern in aqueous $\mathrm{Fe}(\mathrm{II})$ concentration found within the sediment porewaters. Iron(III) reduction is the only source of aqueous Fe(II) to the porewaters, and Fe(III), though abundant [3], is still limited in the wetland due to a lack of external input. Consumption of Fe(II) through FeS precipitation then further limits the aqueous $\mathrm{Fe}(\mathrm{II})$ available for measurement. Aqueous Fe(II) decreases to near detectable limits in the middle of the incursion event (Figure 4 b), likely reflecting this binding of aqueous Fe(II) with reduced sulfide, forming solid phase FeS. As incursion decreases into October and the wetland flushes with freshwater, the sulfides within FeS oxidize first [50], leaving abundant aqueous Fe(II) for measurement (Figure 4b).

The FeS compounds that are hypothesized to form mid-incursion event can potentially be quantified using the AVS and CRS techniques [3,51,52]. While AVS largely quantifies the poorly crystalline and highly reactive FeS compound mackinawite [52], CRS quantifies the more crystalline and stable $\mathrm{FeS}_{\mathrm{x}}$ species [52]. Chromium reducible sulfur is most abundant near the downstream site (Figure 4a). Here, there is sufficient sulfide, potentially accumulating over the course of several incursion events, for secondary CRS phases to precipitate. In contrast, AVS concentrations throughout the site were highly variable with up to $40 \%$ error between replicate cores [3]. While CRS was a much more reliable measure in this sediment, it does not measure amorphous FeS. Therefore, the uncertainty in AVS concentrations leaves a large gap in our understanding of the dynamic and volatile FeS compounds throughout the incursion event.

\subsection{Detailed View of Heterogeneity Parameters under Heavy Salt Water Influence}

The nugget parameter is expected to be lower both with low and high sea salts, indicating more uniformity in the presence or absence of complexes. The larger nuggets were found following the initial inward pulse of saltwater (i.e., in July during the most dynamic period of sea salt change) but not after July, suggesting the introduction of saltwater is related to spatial heterogeneity of the FeS complexes. However, the nugget parameter alone does not provide a complete view of the trends.

July and August display vastly different responses in the water extracted $\mathrm{SO}_{4}{ }^{2-}$ concentration, the number of complexes, and the MSH, especially when comparing the first and second sites (i.e., those sites and months most heavily influenced by saltwater incursion). For example, when observing the most downstream site $(0 \mathrm{~km})$, the water extracted $\mathrm{SO}_{4}{ }^{2-}$ is highest in July (Figure $4 \mathrm{a}$ ). Schoepfer et al. [3] document the highest $\mathrm{SO}_{4}{ }^{2-}$ reduction rates at this site in August, however, suggesting $\mathrm{SO}_{4}{ }^{2-}$ reduction largely consumes the available $\mathrm{SO}_{4}{ }^{2-}$ in August, removing it from the measurable pool and yielding lower available $\mathrm{SO}_{4}{ }^{2-}$ concentrations.

We can hypothesize that the $\mathrm{SO}_{4}{ }^{2-}$ content and the number of FeS complexes are related. However, the relationship between space, time, $\mathrm{SO}_{4}{ }^{2-}$, and the number of complexes is much more dynamic. At $0 \mathrm{~km}$, the most complexes are found in July (Figure 5a), which may reflect the increased available $\mathrm{SO}_{4}{ }^{2-}$ from salt water incursion (Figure $\left.4 \mathrm{a}\right)$. However, the second site $(0.21 \mathrm{~km})$ had a greater number 
of complexes than the first site in July despite lower extractable $\mathrm{SO}_{4}{ }^{2-}$ content. The higher number of complexes is likely related to decreased soil moisture at this second site in the transect (Figure 3a), rather than $\mathrm{SO}_{4}{ }^{2-}$ content. This assertion is supported by the average area per complex (Supplemental information Figure S4). The relationship between the number of pixels, distance, and month suggests that the largest complexes at $0 \mathrm{~km}$ were found in August at the height of incursion and decreased with the flushing of salt water by freshwater. The largest complexes at the second site $(0.21 \mathrm{~km})$ were found later, in October. We hypothesize that decreased soil moisture at $0.21 \mathrm{~km}$ isolates the drier soil particles and associated $\mathrm{SO}_{4}{ }^{2-}$ until later in the season. In contrast, higher soil moisture at the first site may spread out and dilute the $\mathrm{SO}_{4}{ }^{2-}$ and subsequent $\mathrm{FeS}$ in the soil profile in August [13,53-55]. The increased dilution at the first site may explain the fewer number of complexes (i.e., fewer but larger and more connected complexes at $0 \mathrm{~km}$ ).

Soil moisture alone does not explain the trends in the MSH in August, where the first site $(0 \mathrm{~km})$ has the highest MSH. Homogeneity was thought to be limited by soil moisture in July, but the CRS content may be influencing the MSH as well, especially later in the season. The number of individual FeS complexes at the first site in August is substantially lower than in July. The IRIS based FeS measurements only document the amorphous, poorly crystalline sulfide minerals and does not document any crystallization of these minerals to $\mathrm{FeS}_{\mathrm{x}}$, which can occur with the addition of extra sulfide [56,57]. However, CRS measures this more crystalline fraction of reduced inorganic sulfur minerals [58] and peaks in August at the first site (Figure 4c). It is possible, therefore, that this first site has accumulated enough sulfide to transition from an AVS dominated system (amorphous and poorly crystalline FeS species) [51] to a CRS dominated system (crystalline $\mathrm{FeS}_{\mathrm{x}}$ ) and the IRIS plates are not able to measure this transition [24]. Therefore, the remaining AVS on the plate may be more heterogeneous when compared to the second site due to selective or perhaps random crystallization. Acid volatile sulfide was determined in these locations [3], however had up to $40 \%$ error at each site, which restricted the reliability of the data. Future work could include the use of portable x-ray fluorescence, used to scan and map the chemical and elemental composition on the IRIS plate, including those pixels that have transitioned from amorphous to crystalline $\mathrm{FeS}_{\mathrm{x}}$.

In contrast, the second site $(0.21 \mathrm{~km})$ becomes more homogeneous in August and may be a function of the reaction front moving inland or less buildup of sulfide over the years, resulting in more amorphous, AVS-measurable FeS visible on the plates. However, despite differences in the $\mathrm{MSH}$, all values were indicative of more heterogeneity than homogeneity (values $>0.5$ ), suggesting the larger wetland is only marginally influenced by saltwater incursion. This conclusion supports Schoepfer et al. [3], who conclude the presence of an iron-clad wetland that will buffer against the seawater- $\mathrm{SO}_{4}{ }^{2-}$ input for many more years. We hypothesize that with additional $\mathrm{SO}_{4}{ }^{2-}$ (either through larger or longer incursion events), soils will become more homogenous with respect to $\mathrm{FeS}$ as the small and dark complexes currently present become larger and merge, to eventually occupy the entire sediment profile.

In support of this projection, we can see the most upstream site $(1.9 \mathrm{~km})$ had a relatively high MSH (around or above 0.7), indicating high heterogeneity in the absence of increased salt water. This may be due to both the low soil moisture at the upstream site and low $\mathrm{SO}_{4}{ }^{2-}$ content of that incoming water. Together, the lack of water and lack of $\mathrm{SO}_{4}{ }^{2-}$ result in a patchy $\mathrm{FeS}$ soil profile where the low concentrations of $\mathrm{SO}_{4}{ }^{2-}$ cannot be united in the pore spaces to create larger and more uniformly distributed complexes [13,59-61].

In summary, both increased soil moisture and elevated sea salts are suspected to be the driving factor in determining FeS complex formation and subsequent homogeneity. Waterlogging of sediments with $\mathrm{SO}_{4}{ }^{2-}$ rich water both supplies the necessary $\mathrm{SO}_{4}{ }^{2-}$ for microbial $\mathrm{SO}_{4}{ }^{2-}$ reduction and unifies soil pores, therefore more evenly redistributing resources [13,59-61]. The summary statistic of the MSH demonstrates this homogenization of the FeS complexes within the soil profile over the course of the summer incursion event using the IRIS method at the three inland sites. The most downstream site, however, is influenced by the excess sulfide precipitation as CRS species, possibly due to seasonally 
repeated incursion cycles. As such, the IRIS method is limited in its robustness until further statistical measures are refined to determine sulfide concentration on a pixel by pixel basis (See Supplemental Information Figure S5).

\subsection{IRIS Method Determination of FeS Concentrations}

Rabenhorst et al. [24] developed a method to determine sulfide concentrations on IRIS plates. Using this method, average sulfide concentrations across the entire $3 \times 15 \mathrm{~cm}$ section of the plate were determined. We hypothesize that the larger complexes would be lighter in color due to dilution. However, the quantitative values determined via this method (Figure $5 b$ ) were not representative of the qualitative visual analyses. Furthermore, a large amount of detail was lost in the averaging process. For example, the larger complexes were visually often lighter in color than the more numerous smaller complexes (Figure 2a). However, the IRIS derived sulfide concentrations were similar across site and time following salt water incursion, as most distance and time related trends were eliminated through averaging, representing a uniform, higher concentration throughout space and time (Figure 5b).

To further distinguish the derived sulfide concentrations among months, a histogram function was used (Figure 7). This method took the average concentration per plate for each of 25 replicates throughout the four sites. Despite sites being grouped in this analysis, August displays the greatest number of plates with higher sulfide concentrations when compared to June, July and October. Increased sulfide in August supports our hypothesis that August was the height of the incursion season even though water extracted $\mathrm{SO}_{4}{ }^{2-}$ was low. Increased $\mathrm{SO}_{4}{ }^{2-}$ reduction was not discernable when averaging the entire plate sulfide concentrations, suggesting much more work into the statistical background of the complex location and concentration is needed. Furthermore, although complexes were detectable in June, the sulfide concentrations were too low for accurate analysis. Consequently, the use of the IRIS plate method may be limited in low sulfide locations and must be paired with traditional bulk chemical analyses in freshwater sites.

\section{Conclusions}

Here, we have slightly modified the IRIS technique and introduced new quantification methods for FeS identification in wetland sediments. We show how (1) FeS spatial heterogeneity is present in a fresh-to-brackish transitioning wetland, and (2) how increased salt water input altered this heterogeneity, specifically with regard to the $\mathrm{SO}_{4}{ }^{2-}$ input to the wetland. Other factors that may play an important role in the differences in the MSH are the CRS concentrations, the $\mathrm{SO}_{4}{ }^{2-}$ reducing bacteria pool $[59,60]$ and the hydrology on the site [61,62], all which influence amorphous (IRIS measurable) FeS complex formation. Although the hydrology at the site has been described previously [33,34], integration of hydrology with the modified IRIS method will likely aid in our understanding of belowground FeS patterns and our predictive abilities of FeS characteristics.

The presence of FeS largely controls acidity dynamics [6] as well as nutrient and contaminant sorption and mobility $[7,8]$. A more homogeneous sediment may be able to more uniformly retain metals and nutrients sorbed to the FeS structure, naturally mitigating the coastlines against excess waste-containing material (i.e., agricultural or industrial runoff). However, a freshwater wetland experiencing only some saltwater incursion (i.e., high heterogeneity) may not be able to consistently buffer the surrounding waters against pollutants. Therefore, although sulfidization of the sediment is not a threat in these particular fresh-to-brackish transitioning sediments [3], the $\mathrm{pH}$ dynamics during repeated flooding and drying events (and subsequent reduction and oxidation of FeS) [9] must be monitored, as well as the metal and nutrient mobility resulting from potential changes in $\mathrm{pH}$.

Future work into the development of this method should focus on streamlining the plate analysis procedure. The process of transforming photos to coordinates and greyscale values is not difficult in ImageJ, however is time consuming. As a result, the rate limiting step in the analysis procedure is the hand extraction of individual plate coordinate data from ImageJ to a data management software. If this process can be automated through the use of macros, the spatial analysis of the photos will be 
greatly streamlined. Furthermore, alternative statistical methods (i.e., detailed histogram analysis or spot-by-spot analysis of FeS complex sulfide concentrations) will greatly enhance the IRIS method and provide a more direct comparison to traditional AVS and CRS measurements.

Supplementary Materials: The following are available online at http://www.mdpi.com/2571-8789/3/2/25/s1, R code S1: Variogram building, Figure S1: FeS spatial distribution and standards, Figure S2: Example image flow, Figure S3: Example nugget effects. Figure S4: The area per complex per month and distance. Figure S5: Histogram of one plate's pixel by pixel concentrations and their respective frequency.

Author Contributions: Conceptualization, V.S., A.B., T.L., methodology, V.S., A.B., T.L.; software, V.S., T.L.; validation, V.S.; formal analysis, V.S.; investigation, V.S.; resources, V.S., A.B.; data curation, V.S.; writing-original draft preparation, V.S.; writing—review and editing, A.B., T.L., A.H.; visualization, V.S.; supervision, A.B., T.L.; project administration, A.B.; funding acquisition, A.B.

Funding: This research was funded by The National Science Foundation, grant number DEB 1216916.

Acknowledgments: We would like to thank Katie Schlafke and Anna Fedders for their assistance with the field work, Emily Bernhardt for her conceptual contributions, and Niloofar Karimian for assistance with an early draft.

Conflicts of Interest: The authors declare no conflict of interest.

\section{References}

1. Hines, M.M.E.M.; Knollmeyer, S.S.L.S.; Tugel, J.; Tugei, J.B.; Tugel, J. Sulfate reduction and other sedimentary biogeochemistry in a northern New England salt marsh. Limnol. Oceanogr. 1989, 34, 578-590. [CrossRef]

2. Weston, N.B.; Dixon, R.E.; Joye, S.B. Ramifications of increased salinity in tidal freshwater sediments: Geochemistry and microbial pathways of organic matter mineralization. J. Geophys. Res. 2006, 111, 1-14. [CrossRef]

3. Schoepfer, V.A.; Bernhardt, E.S.; Burgin, A.J. Iron clad wetlands: Soil iron-sulfur buffering determines coastal wetland response to salt water incursion. J. Geophys. Res. Biogeosci. 2014, 119, 2209-2219. [CrossRef]

4. Van Dijk, G.; Smolders, A.J.P.; Loeb, R.; Bout, A.; Roelofs, J.G.M.; Lamers, L.P.M. Salinization of coastal freshwater wetlands; effects of constant versus fluctuating salinity on sediment biogeochemistry. Biogeochemistry 2015, 126, 71-84. [CrossRef]

5. Herbert, E.R.; Boon, P.; Burgin, A.J.A.J.; Neubauer, S.C.S.C.; Franklin, R.B.R.B.; Ardón, M.; Hopfensperger, K.N.; Lamers, L.P.M.; Gell, P.; Ardon, M.; et al. A global perspective on wetland salinization: Ecological consequences of a growing threat to freshwater wetlands. Ecosphere 2015, 6, art206. [CrossRef]

6. Burton, E.D.; Bush, R.T.; Sullivan, L.A.; Hocking, R.K.; Mitchell, D.R.G.; Johnston, S.G.; Fitzpatrick, R.W.; Raven, M.; McClure, S.; Jang, L.Y. Iron-Monosulfide Oxidation in Natural Sediments: Resolving Microbially Mediated S Transformations Using XANES, Electron Microscopy, and Selective Extractions. Environ. Sci. Technol. 2009, 43, 3128-3134. [CrossRef]

7. Gao, Y.; van de Velde, S.; Williams, P.N.; Baeyens, W.; Zhang, H. Two-dimensional images of dissolved sulfide and metals in anoxic sediments by a novel diffusive gradients in thin film probe and optical scanning techniques. TrAC Trends Anal. Chem. 2015, 66, 63-71. [CrossRef]

8. Niazi, N.K.; Burton, E.D. Arsenic sorption to nanoparticulate mackinawite (FeS): An examination of phosphate competition. Environ. Pollut. 2016, 218, 111-117. [CrossRef] [PubMed]

9. Karimian, N.; Johnston, S.G.; Burton, E.D. Effect of cyclic redox oscillations on water quality in freshwater acid sulfate soil wetlands. Sci. Total Environ. 2017, 581-582, 314-327. [CrossRef] [PubMed]

10. Borch, T.; Kretzschmar, R.; Kappler, A.; Cappellen, P.V.; Ginder-Vogel, M.; Voegelin, A.; Campbell, K. Biogeochemical Redox Processes and their Impact on Contaminant Dynamics. Environ. Sci. Technol. 2010, 44, 15-23. [CrossRef] [PubMed]

11. Burton, E.D.; Sullivan, L.A.; Bush, R.T.; Johnston, S.G.; Keene, A.F. A simple and inexpensive chromium-reducible sulfur method for acid-sulfate soils. Appl. Geochem. 2008, 23, 2759-2766. [CrossRef]

12. Kefi, S.; Guttal, V.; Brock, W.A.; Carpenter, S.R.; Ellison, A.M.; Livina, V.N.; Seekell, D.A.; Scheffer, M.; Van Nes, E.H.; Dakos, V.; et al. Early warning signals of ecological transitions: Methods for spatial patterns. PLoS ONE 2014, 9, 10-13. [CrossRef] [PubMed]

13. Santner, J.; Larsen, M.; Kreuzeder, A.; Glud, R.N. Two decades of chemical imaging of solutes in sediments and soils-A review. Anal. Chim. Acta 2015, 878, 9-42. [CrossRef] [PubMed] 
14. Johnston, S.G.; Burton, E.D.; Aaso, T.; Tuckerman, G. Sulfur, iron and carbon cycling following hydrological restoration of acidic freshwater wetlands. Chem. Geol. 2014, 371, 9-26. [CrossRef]

15. Ettema, C.H.; Wardle, D.A. Spatial soil ecology. Trends Ecol. Evol. 2002, 17, 177-183. [CrossRef]

16. Bennett, W.W.; Teasdale, P.R.; Welsh, D.T.; Panther, J.G.; Jolley, D.F. Optimization of colorimetric DET technique for the in situ, two-dimensional measurement of iron(II) distributions in sediment porewaters. Talanta 2012, 88, 490-495. [CrossRef] [PubMed]

17. Stockdale, A.; Davison, W.; Zhang, H. Micro-scale biogeochemical heterogeneity in sediments: A review of available technology and observed evidence. Earth-Sci. Rev. 2009, 92, 81-97. [CrossRef]

18. Robertson, D.; Welsh, D.T.; Teasdale, P.R. Investigating biogenic heterogeneity in coastal sediments with two-dimensional measurements of iron(II) and sulfide. Environ. Chem. 2009, 6, 60-69. [CrossRef]

19. Viollier, E.; Rabouille, C.; Apitz, S.E.; Breuer, E.; Chaillou, G.; Dedieu, K.; Furukawa, Y.; Grenz, C.; Hall, P.; Janssen, F.; et al. Benthic biogeochemistry: State of the art technologies and guidelines for the future of in situ survey. J. Exp. Mar. Biol. Ecol. 2003, 285-286, 5-31. [CrossRef]

20. Gao, Y.; Leermakers, M.; Elskens, M.; Billon, G.; Ouddane, B.; Fischer, J.C.; Baeyens, W. High resolution profiles of thallium, manganese and iron assessed by DET and DGT techniques in riverine sediment pore waters. Sci. Total Environ. 2007, 373, 526-533. [CrossRef]

21. Vandenhove, H.; Antunes, K.; Wannijn, J.; Duquène, L.; Van Hees, M. Method of diffusive gradients in thin films (DGT) compared with other soil testing methods to predict uranium phytoavailability. Sci. Total Environ. 2007, 373, 542-555. [CrossRef] [PubMed]

22. Wu, Z.; Wang, S.; Jiao, L.; Wu, F. The simultaneous measurement of phosphorus, sulfide, and trace metals by ferrihydrite/AgI/Chelex-100 DGT (diffusive gradients in thin films) Probe at sediment/water interface (SWI) and remobilization assessment. Water Air Soil Pollut. 2014, 225. [CrossRef]

23. Neubauer, S.C.; Anderson, I.C.; Neikirk, B.B. Nitrogen cycling and ecosystem exchanges in a Virginia tidal freshwater marsh. Estuaries 2005, 28, 909-922. [CrossRef]

24. Rabenhorst, M.C.; Megonigal, J.P.; Keller, J. Synthetic Iron Oxides for Documenting Sulfide in Marsh Pore Water. Soil Sci. Soc. Am. J. 2010, 74, 1383. [CrossRef]

25. Rabenhorst, M.C. A System for Making and Deploying Oxide-Coated Plastic Films for Environmental Assessment of Soils. Soil Sci. Soc. Am. J. 2018, 82, 1301. [CrossRef]

26. Rabenhorst, M.C.; Burch, S.N. Synthetic Iron Oxides as an Indicator of Reduction in Soils (IRIS). Soil Sci. Soc. Am. J. 2006, 70, 1227. [CrossRef]

27. Rabenhorst, M.C. Visual Assessment of IRIS Tubes in Field Testing for Soil Reduction. Wetlands 2010, 30, 847-852. [CrossRef]

28. Vaness, B.M.; Wilson, S.D.; Macdougall, A.S. Decreased root heterogeneity and increased root length following grassland invasion. Funct. Ecol. 2014, 28, 1266-1273. [CrossRef]

29. Zuo, X.A.; Zhao, X.Y.; Zhao, H.L.; Guo, Y.R.; Zhang, T.H.; Cui, J.Y. Spatial pattern and heterogeneity of soil organic carbon and nitrogen in sand dunes related to vegetation change and geomorphic position in Horqin Sandy Land, Northern China. Environ. Monit. Asses. 2010, 164, 29-42. [CrossRef]

30. Lin, Y.; Hong, M.; Han, G.; Zhao, M.; Bai, Y.; Chang, S.X. Grazing intensity affected spatial patterns of vegetation and soil fertility in a desert steppe. Agric. Ecosyst. Environ. 2010, 138, 282-292. [CrossRef]

31. Schlesinger, W.H.; Raikes, J.A.; Hartley, A.E.; Cross, A.F. On the Spatial Pattern of Soil Nutrients in Desert Ecosystems. Ecology 1996, 77, 364-374. [CrossRef]

32. Ardón, M.; Morse, J.L.; Colman, B.P.; Bernhardt, E.S. Drought-induced saltwater incursion leads to increased wetland nitrogen export. Glob. Chang. Biol. 2013, 19, 2976-2985. [CrossRef]

33. Ardón, M.; Montanari, S.; Morse, J.L.; Doyle, M.W.; Bernhardt, E.S. Phosphorus export from a restored wetland ecosystem in response to natural and experimental hydrologic fluctuations. J. Geophys. Res. 2010, 115. [CrossRef]

34. Morse, J.L.; Ardón, M.; Bernhardt, E.S. Greenhouse gas fluxes in southeastern U.S. coastal plain wetlands under contrasting land uses. Ecol. Appl. 2012, 22, 264-280. [CrossRef]

35. Helton, A.M.; Bernhardt, E.S.; Fedders, A. Biogeochemical regime shifts in coastal landscapes: The contrasting effects of saltwater incursion and agricultural pollution on greenhouse gas emissions from a freshwater wetland. Biogeochemistry 2014, 120, 133-147. [CrossRef]

36. Ardón, M.; Helton, A.M.; Scheuerell, M.D.; Bernhardt, E.S. Fertilizer legacies meet saltwater incursion: Challenges and constraints for coastal plain wetland restoration. Elem. Sci. Anth. 2017, 5, 41. [CrossRef] 
37. Ardón, M.; Morse, J.L.; Doyle, M.W.; Bernhardt, E.S. The Water Quality Consequences of Restoring Wetland Hydrology to a Large Agricultural Watershed in the Southeastern Coastal Plain. Ecosystems 2010, 13, 1060-1078. [CrossRef]

38. Neubauer, S.C.; Givler, K.; Valentine, S.S.; Megonigal, J.P. Seasonal Patterns and Plant-Mediated Controls of Subsurface Wetland Biogeochemistry. Ecology 2005, 86, 3334-3344. [CrossRef]

39. Fossing, H.; Jørgensen, B.B. Measurement of bacterial sulfate reduction in sediments: Evaluation of a single-step chromium reduction method. Biogeochemistry 1989, 8, 205-222. [CrossRef]

40. Allen, H.E.; Fu, G.; Deng, B. Analysis of acid volatile sulfide (AVS) and simultaneously extracted metals (SEM) for the estimation of potential toxicity in aquatic sediments. Environ. Toxicol. Chem. 1993, 12, 1441-1453. [CrossRef]

41. Jenkinson, B.J.; Franzmeier, D.P. Development and Evaluation of Iron-Coated Tubes that Indicate Reduction in Soils. Soil Sci. Soc. Am. J. 2006, 70, 183. [CrossRef]

42. Rasband, W.S. ImageJ; U. S. National Institutes of Health: Bethesda, MD, USA, 1997.

43. Pebesma, E. Spatio-temporal geostatistics using gstat. Available online: http://citeseerx.ist.psu.edu/ viewdoc/download?doi=10.1.1.432.106\&rep=rep1\&type=pdf (accessed on 31 March 2019).

44. Pebesma, E.; Bivand, R.S.S. Classes and Methods for Spatial Data: The sp Package. R News 5 (2). 2005, pp. 1-21. Available online: https:/ / cran.r-project.org/doc/Rnews/ (accessed on 31 March 2019).

45. Bivand, R.S.; Pebesma, E.J.; Gomez-Rubio, V. Applied Spatial Data Analysis with R, 2nd ed.; Springer: New York, NY, USA, 2013.

46. Wickham, H. The Split-Apply-Combine Strategy for Data Analysis. J. Stat. Softw. 2011, 40, 1-29. [CrossRef]

47. Redd, A. Dostats: Compute Statistics Helper Functions. 2015, pp. 1-13. Available online: https:/ / github. com/halpo/dostats (accessed on 31 March 2019).

48. Sonderegger, D. SiZer: SiZer: Significant Zero Crossings. 2015, pp. 1-15. Available online: https://github. com/dereksonderegger/SiZer (accessed on 31 March 2019).

49. Lane, D.R.; BassiriRad, H. Diminishing Spatial Heterogeneity in Soil Organic Matter across a Prairie Restoration Chronosequence. Restor. Ecol. 2005, 13, 403-412. [CrossRef]

50. Paul, S.; Kusel, K.; Alewell, C. Reduction processes in forest wetlands: Tracking down heterogeneity of source/sink functions with a combination of methods. Soil Biol. Biochem. 2006, 38, 1028-1039. [CrossRef]

51. Rickard, D.; Morse, J.W. Acid volatile sulfide (AVS). Mar. Chem. 2005, 97, 141-197. [CrossRef]

52. Burton, E.D.; Bush, R.T.; Sullivan, L.A. Sedimentary iron geochemistry in acidic waterways associated with coastal lowland acid sulfate soils. Geochim. Cosmochim. Acta 2006, 70, 5455-5468. [CrossRef]

53. Orr, C.H.; Predick, K.I.; Stanley, E.H.; Rogers, K.L. Spatial autocorrelation of denitrification in a restored and a natural floodplain. Wetlands 2014, 34, 89-100. [CrossRef]

54. Harms, T.K.; Wentz, E.A.; Grimm, N.B. Spatial heterogeneity of denitrification in semi-arid floodplains. Ecosystems 2009, 12, 129-143. [CrossRef]

55. Ekschmitt, K.; Kandeler, E.; Poll, C.; Brune, A.; Buscot, F.; Friedrich, M.; Gleixner, G.; Hartmann, A.; Kästner, M.; Marhan, S.; et al. Soil-carbon preservation through habitat constraints and biological limitations on decomposer activity. J. Plant Nutr. Soil Sci. 2008, 171, 27-35. [CrossRef]

56. Kraal, P.; Burton, E.D.; Bush, R.T. Iron monosulfide accumulation and pyrite formation in eutrophic estuarine sediments. Geochim. Cosmochim. Acta 2013, 122, 75-88. [CrossRef]

57. Burton, E.D.; Bush, R.; Sullivan, L. Fractionation and extractability of sulfur, iron and trace elements in sulfidic sediments. Chemosphere 2006, 64, 1421-1428. [CrossRef]

58. Kallmeyer, J.; Ferdelman, T.G.; Weber, A.; Fossing, H.; Jørgensen, B.B. A cold chromium distillation procedure for radiolabeled sulfide applied to sulfate reduction measurements: Sulfate reduction cold Cr-II method. Limnol. Oceanog. Methods 2004, 2, 171-180. [CrossRef]

59. Concostrina-Zubiri, L.; Huber-Sannwald, E.; Martínez, I.; Flores Flores, J.L.; Escudero, A. Biological soil crusts greatly contribute to small-scale soil heterogeneity along a grazing gradient. Soil Biol. Biochem. 2013, 64, 28-36. [CrossRef]

60. Jackson, R.B.; Caldwell, M. Geostatistical patterns of soil heterogeneity around individual perennial plants. J. Ecol. 1993, 81, 683-692. [CrossRef] 
61. Burt, T.P.; Matchett, L.S.; Goulding, K.W.T.; Webster, C.P.; Haycock, N.E. Denitrification in riparian buffer zones: The role of floodplain hydrology. Hydrol. Process. 1999, 13, 1451-1463. [CrossRef]

62. Burt, T.P.; Pinay, G. Linking hydrology and biogeochemistry in complex landscapes. Progr. Phys. Geogr. 2005, 29, 297-316. [CrossRef]

() (1) (c) 2019 by the authors. Licensee MDPI, Basel, Switzerland. This article is an open access article distributed under the terms and conditions of the Creative Commons Attribution (CC BY) license (http:/ / creativecommons.org/licenses/by/4.0/). 